\title{
Have local stages outlived their usefulness for the New Zealand Pliocene- Pleistocene?
}

\author{
R. M. CARTER \\ School of Earth Sciences \\ James Cook University \\ Townsville, Qld. 4811, Australia
}

\author{
T. R. NAISH \\ Institute of Geological \& Nuclear Sciences \\ P.O. Box 30368 \\ Lower Hutt, New Zealand
}

\begin{abstract}
Stratigraphic subdivision of the New Zealand Pliocene-Pleistocene has its historical basis in biostratigraphy, especially in the shallow marine strata in the Wanganui and East Coast basins, North Island. Internationally, an astronomically calibrated, high resolution timescale is now well established for the PliocenePleistocene, based on predominantly precession-controlled sedimentary cycles in the Mediterranean region, and the mainly obliquity-controlled, high resolution, deep-sea, benthonic oxygen isotope record. Naish and others have recently provided a similar Milankovitch-frequency cyclostratigraphy for the Pliocene-Pleistocene of New Zealand (last 3.6 m.y.), based on the Wanganui Basin record. This cyclostratigraphic record allows numeric ages to be estimated for at least 114 stratigraphic horizons in Wanganui Basin, which are not otherwise dated. Based on this record, we propose new definitions for the boundaries between New Zealand Pliocene-Pleistocene stages. The new boundaries respect traditional biostratigraphic indicators, but are based upon objective markers, mainly magnetic polarity reversals. The two exceptions are the base-Marahauan (equated with the international Pliocene-Pleistocene boundary, at $1.81 \mathrm{Ma}$ ) and the base-Haweran (equated with the base of the Rangitawa Tephra, at $0.34 \mathrm{Ma}$ ). The revised positions and ages for the age/stage and subage/substage boundaries, from older to younger, are: base-Opoitian Stage, base-Thvera subchron, $5.25 \mathrm{Ma}$; base-Waitotaran Stage (= baseWaipipian Substage), Gauss/Gilbert boundary, $3.60 \mathrm{Ma}$; base-Mangapanian Substage, top-Kaena Subchron, $3.03 \mathrm{Ma}$; base-Nukumaruan Stage (= base-Hautawan Substage), Matuyama/Gauss boundary, $2.58 \mathrm{Ma}$; base-Marahauan Substage, Pliocene-Pleistocene boundary, $1.81 \mathrm{Ma}$; baseCastlecliffian Stage (= base-Okehuan Substage), baseJaramillo Subchron, $1.07 \mathrm{Ma}$; base-Putikian Substage, Brunhes/Matuyama boundary, $0.78 \mathrm{Ma}$; base-Haweran Stage, base-Rangitawa Tephra, 0.34 Ma.
\end{abstract}

Keywords sea-level; Milankovitch; Pliocene-Pleistocene; Wanganui Basin; stage; chronostratigraphy

G97029

Received 15 May 1997; accepted 27 April 1998

\section{INTRODUCTION}

The discipline of stratigraphy has undergone two major conceptual shifts over the last 40 years, which together bear on the matters discussed in this paper.

First, the technique of sequence stratigraphy (Payton 1977; Vail et al. 1991; Miall 1996) has revolutionised our understanding of the processes of sedimentary rock accumulation, particularly at broader, basinal scales. More recently, sequence stratigraphy has been interwoven with the development of astronomical (and therefore quantitative) cyclostratigraphy to produce a revolution in our understanding of late Neogene sedimentary rhythmicity (Hays et al. 1976; Hilgen 1987; Saul et al. in press).

The second conceptual change arose from the realisation of the importance of separating the definition of stratigraphic units from their correlation (Campbell 1959; Hughes et al. 1967; Carter 1974). Following widespread acceptance of this distinction, the traditional biostratigraphic methods by which the international geological timescale was previously rather loosely defined have been replaced by internationally agreed stratotype markers ("golden pegs", now termed GSSP for Global Stratotype Section and Point) at the base, and only the base, of each period/system of the scale (e.g., Bassett 1985; Remane et al. 1996). The same approach will in due course be extended to the definitions of constituent ages/ stages throughout the stratigraphic column (e.g., House 1988). At the same time as stratotype markers were being established (e.g., base-Cambrian boundary, Brasier et al. 1994; base-Devonian boundary, Martinsson 1977), there was a spectacular mushrooming of new methods whereby strata could be correlated with the new and rigorously defined timescale. Particularly important new techniques include magnetic stratigraphy, isotopic stratigraphy, cyclostratigraphy, and aspects of numeric stratigraphy (including accelerator radiocarbon dating, isothermal plateau fission track dating, argon/argon dating, and individual zircon crystal dating using the ion microprobe). Application of these techniques has allowed the synchroneity of individual bioevents to be tested, with the scarcely unexpected result that some zone fossils have synchronous first or last appearances, whilst others are time transgressive (e.g., Thierstein et al. 1977; Morley \& Shackleton 1978).

Throughout this revolution in stratigraphic methodology, it has been taken as self-evident that the "international" geological timescale would be redefined with particular respect to the local biostratigraphic units which form its historical basis, which is largely in terms of biostratigraphic stages from Europe and North America, though not necessarily using their original type localities. We have no quarrel with this sensible approach. Meanwhile, however, other local stage systems, such as that in New Zealand, have continued to be used as if nothing has changed. In fact, a great deal has changed. In this paper, therefore, we discuss whether it is useful to perpetuate the New Zealand Pliocene- 
Pleistocene stages, and propose the redefinition of their boundaries based on criteria other than biostratigraphy.

\section{THE PLIOCENE-PLEISTOCENE BOUNDARY}

During the revitalisation of stratigraphy over the last half century, no stratigraphic horizon has been subject to more controversy than the definition of the Pliocene-Pleistocene epoch/series boundary. In one sense, this boundary was the first "golden peg" to be driven in, when a Temporary Commission of the International Geological Congress recommended that the boundary should be located at the first sign of climatic deterioration in the Italian marine Neogene succession, which in the view of the Commission was marked by the base of the Calabrian Stage (King \& Oakley 1950). Provoked by the unfortunate ambiguity of this and later definitions, a spirited and lengthy controversy arose as to whether the Pliocene-Pleistocene boundary was climatic or stratigraphic in nature, where its type locality should be located (for there was also ambiguity as to the location of the type locality for the Calabrian Stage), and whether macrofossils, microfossils, nannofossils, magnetic stratigraphy, isotope stratigraphy, or even hominid evolution should be central to its definition (see historical summary in, e.g., Berggren \& van Couvering 1979). The matter was finally resolved by designation of the boundary at the base of marine claystones conformably overlying sapropel bed e in the Vrica section, southern Italy (Aguirre \& Pasini 1985). Thus, like other designated international boundary stratotypes, that for the Pliocene-Pleistocene is now firmly based on physical stratigraphy, and is located a little below the top of the Olduvai Subchron, with an estimated age of 1.81 Ma (Hilgen 1991a; Lourens et al. 1996b).

Within New Zealand, many attempts were made during this time to locate the Pliocene-Pleistocene boundary within the fossiliferous and well-exposed Quaternary successions which occur widely, especially in North Island (e.g., Fleming 1953a, b; Kennett et al. 1971; Jenkins 1971; Te Punga 1981). Though they contributed to our understanding of local correlation within New Zealand, these studies inevitably failed in their main objective because of the prevailing lack of agreement as to the position of the international boundary. Since the designation of Vrica as the type section, however, the precise location of the Pliocene-Pleistocene boundary in New Zealand has been estimated by Naish et al. (1996) to occur at the base of the highstand systems tract siltstone of Rangitikei River cyclothem 17, corresponding to the top of interglacial oxygen isotope stage 65 , and lying within the top of the Olduvai Subchron.

Recent developments in the astronomical calibration of sedimentary cycles have provided an alternative method of assigning an absolute age to the Pliocene-Pleistocene boundary and adjacent strata (Shackleton et al. 1990; Hilgen $1991 \mathrm{a}, \mathrm{b}$; Tiedemann et al. 1994; Shackleton et al. 1995a, b; Lourens et al. 1996a, b). In such studies, proxy climatic records are tuned to the variations of the Earth's orbit: namely, eccentricity, obliquity, and precession (e.g., Laskar 1990; Berger \& Loutre 1991; Quinn et al. 1991). Tuned timescales have proved to be of higher resolution and accuracy than conventional timescales based on linear interpolation between radiometrically dated calibration points in seafloor magnetic anomaly sequences (Berggren et al. 1995), and show that the radiometric ages are consistently too young by $5-7 \%$. An astronomically based. cyclostratigraphy for the last $3.5 \mathrm{Ma}$ for Wanganui Basir. New Zealand, has recently been presented by Naish et al (1997), and forms the basis for the reassessment we makt below of the local New Zealand biostratigraphic stages.

\section{NEW ZEALAND PLIOCENE-PLEISTOCENE STAGES}

New Zealand's isolated location in temperate latitudes $\mathrm{c}$ the southwest Pacific Ocean is accompanied by a high degrer: of endemism in its marine faunas. Predictably, therefore, a local biostratigraphic stage system arose as an aid to the correlation and subdivision of New Zealand Cenozoic sediments, dating back to Thomson (1916). Stages were initially based upon benthic invertebrates such as molluses, brachiopods, and echinoderms, but pioneering work by Harold Finlay in the 1930s on microfossils (Finlay 1939), and especially planktonic foraminifers, led to a greatly increased accuracy of correlation, and to the dating of the thick, massive, "unfossiliferous" mudstones and siltstones which characterise many New Zealand Cenozoic sedi. mentary basins (Finlay \& Marwick 1940, 1947). Until the 1970 s, the recognition of stage boundaries, and correlation. was based almost exclusively upon biostratigraphy (Beu \&: Maxwell 1990), and the "stages" were in fact oppelzones in the sense of the international stratigraphic guide (Carter 1974).

The local biostratigraphic subdivision worked well $\mathrm{fcr}$ older Cenozoic sedimentary rocks. However, for younger Pliocene-Pleistocene strata, an increasing incidence 0 modern species, and wide regional variations in facies, mads the application of biostratigraphy difficult (e.g., Borehar 1963; Beu 1969; Beu et al. 1977). Nonetheless, late Neogen climatic detereoration resulted in the extinction during the Pliocene of some established warm-water species (e.g., the molluscs Lamprodomina and Polinices), and the arrival of cold-water newcomers in the Pleistocene (e.g., Zygochlamys delicatula, Eucominia nassoides) (Fleming 1944; Beu 1990). Such faunal changes were used for the characterisation of the successively younger Kapitean Stage, Opoitian Stage, Waitotaran Stage (Waipipian and Mangapanian Substages), Nukumaruan Stage (Hautawan and Marahauan Substages), and Castlecliffian Stage (Okehuan and Putikian Substages) (Fleming 1944, 1947, 1953a, b, 1955, 1957, 1959, 1962: Finlay \& Marwick 1947; Vella 1963; Edwards 1987) (Fig. 1) Subsequently, the substages of the Waitotaran have been upgraded to full stage rank (Hornibrook et al. 1989) recommendation has been made to discard the substages $0:$ the Nukumaruan and Castlecliffian (Beu 1969, 1995), and the Haweran Stage has been introduced for sediments deposited in the last c. 350000 years, which mostly represen: surficial terrace treads from around New Zealand (Beu e: al. 1987). Thus, the most widely accepted current stage classification for the New Zealand Pliocene-Pleistocene comprises the Kapitean, Opoitian, Waipipian, Mangapanian, Nukumaruan, Castlecliffian, and Haweran Stages. The detailed biostratigraphy of these stages has been treated in many publications. Readers are referred to Marwick (1924a, b), Boreham (1963), Beu (1969), Neef (1970), Beu et al. (1977), Hornibrook (1981, 1982a, b), Hornibrook et al. (1989), Beu \& Maxwell (1990), Scott et al. (1990), and to works cited therein. 


\begin{tabular}{|c|c|c|c|c|c|c|c|c|c|c|}
\hline \multicolumn{2}{|c|}{ FLEMING '53 } & \multirow{2}{*}{$\begin{array}{c}\text { FLEMING '62 } \\
\text { Stage }\end{array}$} & \multirow{2}{*}{$\begin{array}{c}\text { VELLA '63 } \\
\text { Stage } \\
\end{array}$} & \multicolumn{2}{|c|}{ BEU '69 } & \multirow{2}{*}{$\begin{array}{l}\text { BEU '95 } \\
\text { Stage } \\
\end{array}$} & \multicolumn{4}{|c|}{ THIS PAPER } \\
\hline Stage & Substage & & & Stage & Substage & & Stage & Substage & Base & Age \\
\hline \multicolumn{2}{|c|}{ Hawera series } & Hawora S. & Haweras. & \multicolumn{2}{|c|}{ Hawera Serles } & Haweran & Haweran & & Rangitawa Ash & $0.34 \mathrm{Ma}$ \\
\hline \multirow[b]{2}{*}{ Castlecliffian } & Putikian & Castlecliffian & Castlecliffian & \multirow[b]{2}{*}{ Castlediffian } & Putikian & \multirow[b]{2}{*}{ Castlecliffian } & \multirow[b]{2}{*}{ Castlecliffian } & Putikian & Brunhes/Matuyama & $0.78 \mathrm{Ma}$ \\
\hline & Okehuan & Okehuan & Okehuan & & Okehuan & & & Okehuan & Base-Jaramillo & $1.07 \mathrm{Ma}$ \\
\hline \multirow[b]{2}{*}{ Nukumaruan } & Marahauan & Nukumaruan & Nukumaruan & \multirow[b]{2}{*}{ Nukumaruan } & & \multirow[b]{2}{*}{ Nukumaruan } & \multirow[b]{2}{*}{ Nukumaruan } & Marahauan & Plio-Pleistocene & $1.81 \mathrm{Ma}$ \\
\hline & Hautawan & Hautawan & Hautawan & & & & & Hautawan & Matuyama/Gauss & $2.58 \mathrm{Ma}$ \\
\hline \multirow[b]{2}{*}{ Waitotaran } & Mangapanian & Waitotaran & Waitotaran & Mangapanian & & Mangapanian & & Mangapanian & Top-Kaena & $3.03 \mathrm{Ma}$ \\
\hline & Waipipian & Waipipian & Waipipian & Waipipian & & Waipipian & Waitotaran & Waipipian & Gauss/Gilbert & $3.60 \mathrm{Ma}$ \\
\hline Opoitian & & Opoitian & Opoitian & Opoitian & & Opoitian & Opoitian & & Base-Thvera & $5.25 \mathrm{Ma}$ \\
\hline
\end{tabular}

Fig. 1 Modern development of the New Zealand Pliocene-Pleistocene stage classification.

The most pronounced faunal change within New Zealand Pliocene-Pleistocene sediments occurs at the traditional boundary between the Mangapanian and Nukumaruan (formerly Waitotaran and Nukumaruan) Stages. Here, amongst other bioevents, the cold-water scallop Zygochlamys delicatula makes its first appearance. An equivalence between the Waitotaran-Nukumaruan and Pliocene-Pleistocene boundaries was adopted as official Geological Survey mapping policy, and therefore as a de facto New Zealand standard, in a memorandum distributed by Survey Director L. I. Grange on 20 July 1953 (Edwards et al. 1981). This memorandum was probably instigated by C. A. Fleming (Alan Beu pers. comm.), who was the first author to suggest this correlation in print (Fleming 1953a).

Recognition of the Pliocene-Pleistocene boundary apart, the biostratigraphic subdivision of the Pliocene-Pleistocene has come to rely heavily on the stratigraphic distribution of pectinid bivalves (Sectipecten, Phialopecten, Kaparachlamys, Zygochlamys, and Pecten s.s.) (Fleming 1957; Beu 1995) and struthiolariid gastropods (Callusaria, Struthiolaria, and Pelicaria) (Marwick 1924b; Neef 1970; Beu 1995). Many of the scallops were probably mobile epifauna, but they are strongly facies-controlled. This, together with regional endemism of the struthiolariids, often makes precise correlation difficult. For example, the traditional Pliocene-Pleistocene boundary indicator $Z$. delicatula has its first appearance in oxygen isotope stage 98 in the Wanganui Basin (Naish et al. 1997, in press), and in stage 86 in the Mangaopari Basin (Gammon 1997). Additional difficulties with correlation arise because the Opoitian Stage is often characterised by deep-water siltstone facies, and because the Nukumaruan and Castlecliffian Stages are separated in their type section by a substantial early Pleistocene unconformity (Fleming 1953a).

The time has come to examine whether non-biostratigraphic methods would be more useful for subdividing the New Zealand Pliocene-Pleistocene, or, indeed, whether local stage subdivisions are now needed at all.

\section{THREE NEW CRITERIA FOR CORRELATION}

Biostratigraphy remains a most important tool for correlation, but the last 20 years have seen the refinement of three other high-quality criteria for correlation of the Pliocene-Pleistocene, namely, oxygen isotope ratios, paleomagnetism, and tephrochronologic dating. Jenkins
(1971) and Vella (1975) long ago recognised that the accurate correlation of the New Zealand Pliocene-Pleistocene would eventually come to rest upon criteria other than biostratigraphy, as exemplified by the comment that "the best hope for defining the true boundaries through all of the New Zealand Late Neogene is to use radiometric and paleomagnetic dates to calibrate sequences at appropriate places, and thus enable the use of endemic fossils as well as the few useful cosmopolitan forms" (Vella 1975, p. 91). From a global perspective, the oxygen isotope scale has recently become established as the de facto means of subdivision of geological time since c. 2.5 Ma (Shackleton \& Opdyke 1973; Raymo et al. 1989; Ruddiman et al. 1989). Because the icevolume signal that is represented by the isotope scale is forced by Milankovitch orbital variations (especially the 41000 yr tilt signal; Hays et al. 1976), astronomically tuned timescales can be constructed back to $5 \mathrm{Ma}$ and beyond (Hilgen 1991 a, b; Shackleton et al. 1995a, b; Lourens et al. 1996a). Since the 1970 s, these newer correlation criteria have become increasingly important in New Zealand, as summarised recently by Pillans et al. (1994) and Naish et al. (1996, 1997, in press). For example, paleomagnetic characterisation of the New Zealand Pliocene-Pleistocene has been attempted by Kennett \& Watkins (1974), Seward et al. (1986), Turner \& Kamp (1990), and Pillans et al. (1994); tephrochronologic studies include those of Ninkovitch (1968), Seward (1974, 1976, 1979), Milne (1973a-c), Boellstorff \& Te Punga (1977), Watkins \& Huang (1977), Nelson et al. (1985a), Bussell \& Mildenhall (1990), Kamp (1990), Shane (1990, 1994), Kohn et al. (1992), Alloway et al. (1993), Pillans et al. (1993), and L. Carter et al. (1995); and correlation of Pliocene-Pleistocene shallow marine cyclothems with the oxygen isotope scale has been demonstrated by Beu \& Edwards (1984), Abbott \& Carter (1994), Naish \& Kamp (1997), and Saul et al. (in press).

The new, physical methods for correlation have the advantage of being applicable to sediments from a wide variety of facies, including shallow marine, deep marine, and nonmarine environments. Each method also has its own advantages and disadvantages for use as age/stage boundary markers, as discussed further below.

\section{Oxygen isotope stratigraphy}

Emiliani (1955) introduced the use of numbered "stages" for the cyclic climatic fluctuations of the late Pleistocene, which he measured using foraminifers from deep-sea cores. 
He recognised (Emiliani 1966) 17 intervals of alternating colder and warmer climate over what he estimated to be the last 430000 years. The availability of more and longer cores resulted in the stratigraphic record and the stage numbering system being extended further back in time by Shackleton \& Opdyke (1973, 1976; to stage 23), van Donk (1976; to stage 41), Williams et al. (1988; to stage 63), and eventually to the full set of 104 stages by Ruddiman et al. (1989) and Raymo et al. (1989), who tuned the stages to the 41000 year obliquity cycle back to the base of the Matuyama Chron. Older isotope stages, through the Gauss and into the Gilbert Chron, have been numbered according to the chron in which they occur, but are not yet consistently recognisable worldwide (Tiedemann et al. 1994; Shackleton et al. 1995a, b; Lourens et al. 1996a).

Emiliani (1955) initially defined his isotope stage boundaries by reference to a model of sinusoidal temperature changes through time, rather than with respect to the actual core measurements. Later authors have mostly followed Shackleton \& Opdyke (1973) in recognising the stage boundaries at specific depths in particular cores, corresponding to the point of change between inferred glacial and interglacial episodes. Thus, the isotope stages in use today differ in kind from traditional biostratigraphic stages in: (1) being much shorter (mostly 41000 years) than the several million year length of a typical biostratigraphic stage; (2) having boundaries set at the point of maximum rate of change between the inferred extremes of the climatic cycle; and (3) being based on a set of physically determinable measurements which, after presuming their 41000 year Milankovitch frequency, and after calibration against some independent measure of age, allows the interpolation of numeric ages for each boundary.

The estimated error for the boundary between particular oxygen isotope stages depends upon the resolution of the stratigraphic record being measured, and therefore in particular the sedimentation rate. At best, however, in regions of high and continuous sedimentation, and little bioturbation, the error may be as short as the mixing period of the global ocean (i.e., c. 1000 years; Shackleton \& Opdyke 1973; Hays $\&$ Shackleton 1976). The oxygen isotope record is therefore a very high quality, high resolution method of correlation, particularly in oceanic sedimentary facies. It is theoretically possible, but much more difficult, to use oxygen isotope analysis for the correlation of shallow water continental margin sediments. The difficulties arise because: (1) sediments deposited in sea-level highstand depths less than about $100 \mathrm{~m}$ contain numerous unconformities caused by repetitive sea-level withdrawal during glaciations, and therefore have time missing at each unconformity; and (2) the effects of freshwater runoff and evaporation cause wide variations in the isotope ratio of ambient coastal waters, which obscures the global ice volume signal (e.g., Gammon 1997). Despite these problems, Kamp (1978), Beu \& Edwards (1984), Beu et al. (1987), Black (1992), Abbott \& Carter (1994), Naish \& Kamp (1997), Naish et al. (1997), and Gammon (1997) have shown that it is possible to make correlations between individual New Zealand continental margin glacio-eustatic sequences and the oceanic oxygen isotope scale.

The oxygen isotope stages are often viewed as a timescale in their own right. Though the entire isotope curve comprises a time series of unique configuration, at low or partial resolution any one part of it tends to simulate a binary (glacial/interglacial) signal. Therefore, and useful though it is for high resolution studies of complete oceanic sections. the oxygen isotope record is not particularly suitable for use in redefining the boundaries of the traditional New Zealand stages. Oxygen isotope measurements also suffer from the disadvantage that they are not easily applied in nonmarine or shallow water strata, nor suitable for volcanic rocks.

\section{Magnetostratigraphy}

The major changes in the Earth's magnetic polarity history over the last few million years have been well established since publication of the Cox et al. (1964) polarity timescale The most widely used and recent version of this scale, which has been adjusted to fit the cyclostratigraphic record during the Pliocene-Pleistocene, is that of Cande \& Kent (1995) Importantly, magnetic reversals are registered in a wide variety of sedimentary and volcanic rocks, both marine and nonmarine, and it is estimated that a typical magnetic reversal occurs over a period of 2000-5000 years (Opdyke 1968; Harland et al. 1990). These features make magnetic polarity stratigraphy effectively isochronous, and therefore a superior method of global, cross-facies correlation.

However, the magnetic polarity record is strictly binary in nature, that is, there is nothing distinctive about a particular $\mathrm{N} / \mathrm{R}$ or $\mathrm{R} / \mathrm{N}$ reversal, unless and until some other broad age criteria are available. For instance, the R-N-R-N polarity sequence identified at Rewa Hill in the Rangitike valley by Seward et al. (1986) was correlated with the Matuyama - Jaramillo-Matuyama - Brunhes intervals by Seward et al., but with the Matuyama - Cobb MountainMatuyama - Jaramillo intervals by Pillans et al. (1994). Choosing between such alternatives requires independent age estimates to be available. A second problem stems from the mixed polarity "flutter" which occurs near some reversa] boundaries. For example, the top of the Olduvai (normal) Subchron is known to contain a short reversed interval at the type section of the Pliocene-Pleistocene boundary at Vrica (Zijderveld et al. 1991). In New Zealand, Gammon (1997) and Gammon \& Barton (in press) have described what appear to be equally valid normal and reversed polarity determinations for siltstones of the same sequence in two adjacent sections. The sediments are of latest Pliocene age (sequence P-4, correlated with oxygen isotope stage 71) and can be directly traced on the ground between localities in Mangaopari and Ngarara Streams.

These drawbacks notwithstanding, the paleomagnetic stratigraphy of the New Zealand Pliocene-Pleistocene is now moderately well known (see summary in Naish et al. 1996) and the advantages of using international paleomagnetic boundaries to subdivide the many and varied PliocenePleistocene rocks in New Zealand are great. We have therefore favoured the use of major polarity reversals for most of our suggested stage boundary redefinitions.

\section{Tephrochronology}

During the late Neogene, explosive eruptions from silicic arc volcanoes in the central North Island of New Zealand resulted in the wide distribution of airborne and waterborne ash, for distances of $500 \mathrm{~km}$ and more (L. Carter et al. 1995) Many such tephras occur throughout the sedimentary record of the Wanganui and Hawke Bay Basins, and estimates of their numeric ages based on fission track, potassium-argon 


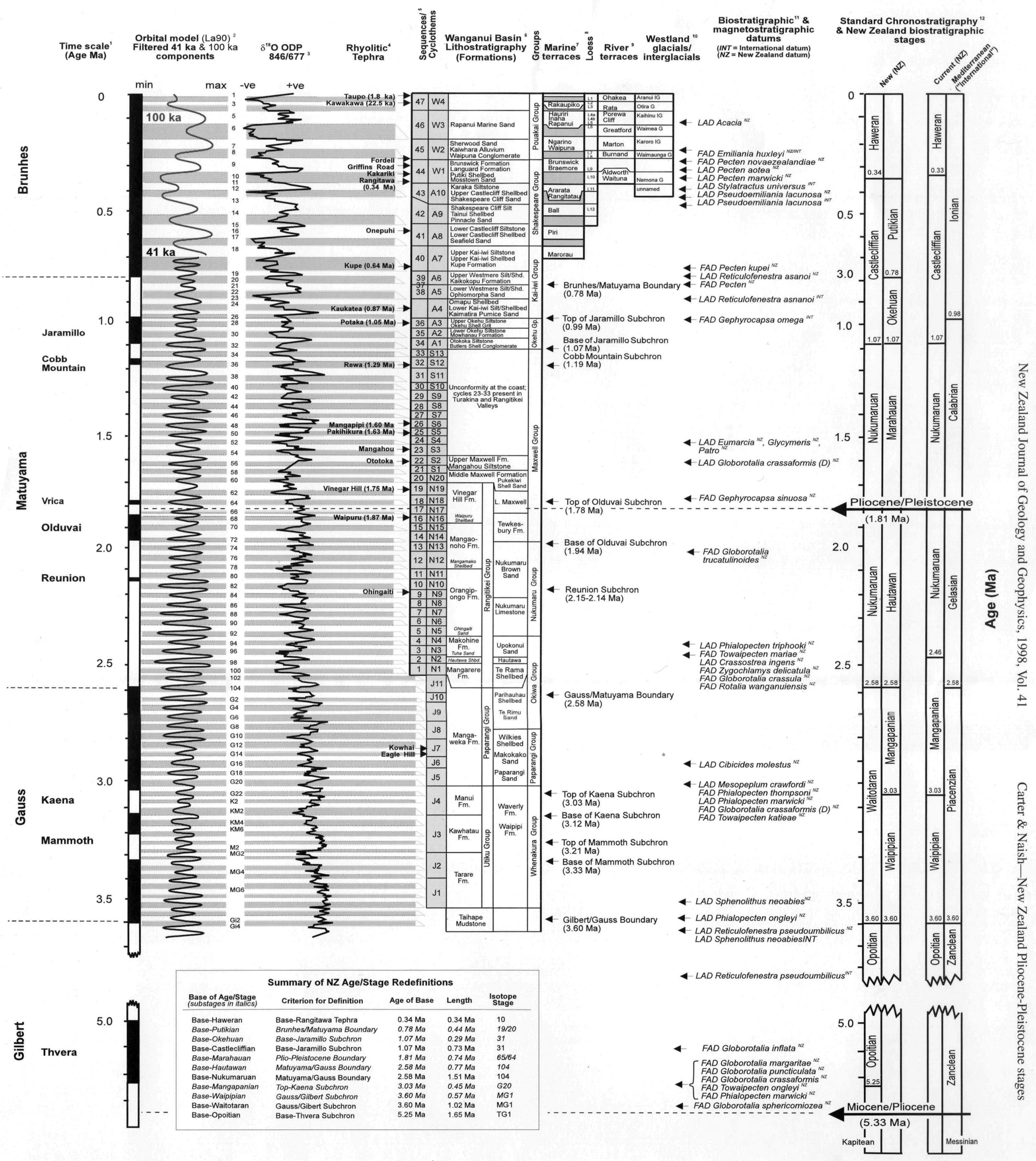

Fig. 2 Cyclostratigraphic subdivision of the New Zealand Pliocene-Pleistocene, based upon the Wanganui Basin succession. After Naish et al. (in press), but with the New Zealand stage boundaries adjusted to fit the recommendations made in this paper.

${ }^{1}$ Timescale after Lourens et al. (1996).

${ }^{2}$ Orbital time series of obliquity (41 ka) and eccentricity (100 ka) from Laskar (1990).

${ }^{3}$ Composite benthonic oxygen isotope record after Shackleton et al. (1995a; stages Gi4-63) and Shackleton et al. (1990; stages 63-1).

${ }^{4}$ Tephrostratigraphy after Milne (1973a, b), Seward (1976), Boellstorff \& Te Punga (1977), Pillans (1994), Pillans et al. (1994), Naish \& Kamp (1995), and Journeaux et al. (1996). Tephrochronology used follows: Waipuru Tephra, ITPFT age 1.87 $\pm 0.15 \mathrm{Ma}$ (Naish et al. 1996); Vinegar Hill Tephra, ITPFT age $1.75 \pm 0.13$ Ma (Naish et al. 1996); Pakihikura Pumice, ITPFT age 1.63 \pm 0.15 Ma (Alloway et al. 1993); Mangapipi Ash, ITPFT age 1.60 $\pm 0.18 \mathrm{Ma}$ (Shane et al. 1996); Rewa Pumice, ITPFT age 1.29 $\pm 0.12 \mathrm{Ma}$ (Shane et al. 1996); Potaka Tephra, Ar/Ar age $1 \mathrm{Ma} \pm 5 \%$ (Shane 1994; Wilson et al. 1995); Potaka Tephra, ITPFT age 1.05 $\pm 0.05 \mathrm{Ma}$ (Alloway et al. 1993); Kaukatea Ash, ITPFT age $0.87 \pm 0.05 \mathrm{Ma}$ (Shane et al. 1996); Kupe Tephra, ITPFT age 0.63 \pm 0.08 Ma (Shane et al. 1996); Rangitawa Tephra, ITPFT age 0.34 \pm 0.03 Ma (Alloway et al. 1993); Kawakawa Tephra, 24 ka (calendar years, Wilson et al. 1988; Shepherd \& Price 1990; Pillans et al. 1993).

${ }^{5}$ Composite cyclostratigraphy (sequences 1-47) after Saul et al. (in press) and Carter et al. (1997). "J" sequences after Journeaux et al. (1996). "N" sequences after Naish \& Kamp (1995, 1997). "S" sequences after Saul (unpubl. data). "A" sequences after Abbott \& Carter (1994). "W" sequences after Woolfe (unpubl. data).

${ }^{6}$ Wanganui Basin lithostratigraphy after Fleming (1953a), Naish \& Kamp (1995), and Journeaux et al. (1996).

${ }^{7}$ Marine terrace stratigraphy and chronology from Pillans $(1983,1990)$.

${ }^{8}$ Loess stratigraphy from Milne (1973a, b, c), Pillans (1988, 1990), Wilde \& Vucetich (1988, summarised in Pillans 1994).

${ }^{9}$ River terrace chronology modified from Milne (1973a, b, c).

${ }^{10}$ Correlations of glacial and interglacial stages to the oxygen isotope scale after Suggate (1990) and Pillans (1991).

${ }^{11}$ Biostratigraphic datums from Fleming (1953a), Hornibrook (1981), Scott (1982), Beu \& Edwards (1984), Beu et al. (1987, 1990), Hornibrook et al. (1989), Bussell \& Mildenhall (1990), Naish \& Kamp (1995), Morgans et al. (1996), A. R. Edwards pers. comm., A. G. Beu pers. comm. INT denotes the international position and age of bioevents. NZ denotes the local New Zealand position and age of bioevents.

12Magnetostratigraphic datums within Wanganui Basin sediments as follows: Thvera Subchron, Mammoth Subchron, Kaena Subchron, Gilbert/Gauss boundary after Wilson (1993) and Journeaux et al. (1996); G/M boundary after Naish et al. (1996); Reunion Subchron from Seward et al. (1986); Olduvai Subchron after Naish et al. (1996); Cobb Mountain Subchron after Pillans et al. (1994); Jaramillo Subchron and Matuyama/Brunhes boundary after Turner \& Kamp (1990) and Pillans et al. (1994). 
or argon-argon dating have been important for calibrating the New Zealand biostratigraphic scale (see summaries in Pillans et al. 1994; Naish et al. 1996).

Individual tephra are more distinctive than isotope excursions or polarity reversals, in that their geochemistry can generally be separated by careful microprobe analyses (Shane \& Froggatt 1991; Shane 1994; Pillans et al. 1994). Also, tephras are equally distributed through marine and nonmarine facies, and can sometimes be equated with flows from the same eruption near the source. On the other hand, despite their intrinsically widespread nature, tephras often have a patchy regional distribution, and can be reworked through a thickness of strata (in the Pliocene-Pleistocene, sometimes even into into younger sequences). We have therefore chosen only one tephra as the basis for a redefined stage base (the Rangitawa Tephra for the base-Haweran), in a situation where there is no suitable polarity reversal available for the redefinition.

\section{REDEFINITION OF NEW ZEALAND PLIOCENE- PLEISTOCENE STAGES}

It is clear that, like biostratigraphy, none of the three methods discussed above is without its drawbacks when considered for use as a stage boundary indicator. However, we note that the oxygen isotope stages are already in use as a high resolution timescale for New Zealand strata, as part of the increasing internationalisation of studies of the New Zealand Pliocene-Pleistocene (cf. Fleming 1955, 1975 with Nelson et al. 1985b and Naish et al. in press). Accordingly, and insofar as they are still necessary, the best way of treating the traditional local stages is to use them for bundling a number of oxygen isotope stages in a way which respects traditional biostratigraphic distributions, but which is also based upon the more objective boundaries provided by either a magnetic reversal or by a widespread and distinctive volcanic ash.

The principles we have followed in our proposed boundary redefinitions are an extension of those outlined by Campbell (1959), Hughes et al. (1967), and Carter (1974) and include:

(1) each stage or substage must have its base defined by a single, objective criterion, using either a designated stratigraphic marker point in a nominated section, or a widely recognisable event such as a paleomagnetic chron boundary;

(2) redefined boundaries are located as near as practicable to the traditional or historical boundary;

(3) stage boundary definitions based on multiple criteria are rejected or amended; e.g., the suggestion that the base of the Nukumaruan should be defined by the first occurrence of Zygochlamys delicatula and Globorotalia crassula (Morgans et al. 1996); and

(4) correlation of New Zealand strata with the stages so defined, and correlation of the New Zealand stages with the international timescale, is achieved using all criteria available in the Pliocene-Pleistocene; paleomagnetics, isotope stratigraphy, cyclostratigraphy, and tephrochronology are all important, in addition to conventional biostratigraphy.
We note the comments of Beu (1995) that the substages of the Nukumaruan (Hautawan, Marahauan) and Castlecliffian (Okehuan, Putikian) are not recognisable New Zealand-wide using faunal criteria, but it does not necessarily follow that the substages are therefore without value. In particular, after our redefinition, there will be a close match of boundaries between the Mediterranean and New Zealand units (Opoitian almost coincident with the Zanclean; Waitotaran equivalent to the Piacenzian; Hautawan equivalent to the Gelasian; Marahauan with the same base as the Calabrian) (Fig. 2). Additionally, because the base of the Putikian Substage is tied to the Brunhes/Matuyama polarity change, it will be equivalent to the proposed global stratotype for the lower/middle Pleistocene boundary (Pillans 1994; Cita \& Castradori 1997). Thus, the New Zealand stages and substages almost dovetail with established and pending international subdivisions. Therefore, we prefer that magnetostratigraphic criteria should be adopted for the redefinition of the New Zealand Pliocene-Pleistocene substages and stages where it is feasible to do so. One boundary, the base of the Marahauan Substage, is equated with the international Pliocene-Pleistocene boundary (which anyway lies within 50000 years of the top of the Olduvai Subchron), and another, the base of the Haweran Stage, is taken as the base of the Rangitawa Tephra.

We recommend, therefore, the redefinitions of New Zealand Pliocene-Pleistocene ages/stages and subages/ substages shown in Fig. 2. As thus redefined, the Opoitian Age is estimated to last $1.65 \mathrm{~m} . \mathrm{y}$., and the following seven subage intervals range from $0.29 \mathrm{~m} . \mathrm{y}$. (Okehuan) to 0.77 m.y. long (Hautawan), with an average length of $0.50 \mathrm{~m} . \mathrm{y}$. The traditional type sections for each age/stage retain their usefulness and significance, but if magnetostratigraphic boundaries are adopted then the type sections will no longer serve as boundary stratotypes. Rather, each will act as an exemplar of the typical faunas and sediments of its age/stage, in a fashion similar to that discussed by Fleming (1953a) and Carter (1970, pp. 352-353).

\section{CONCLUSIONS}

We acknowledge that the historical antecedents of New Zealand Pliocene-Pleistocene stages lie in biostratigraphy. That said, the time has come to accept that biostratigraphy is unsuited for use as the sole criterion for correlation of young strata, and to utilise as well other pragmatic means of defining and correlating the local stages. Though we anticipate that local stages may ultimately fall into disuse, to be replaced by global application of astronomically tuned climatic cycles, there remains a need for their use for the time being, but only if they are more usefully defined than is presently the case.

The answer to the question we posed in the title of this paper, therefore, is "not quite yet", to which should be added the rider, "but probably eventually". In the meantime, we suggest that the most useful way to apply the local New Zealand Pliocene-Pleistocene stages (and substages, indicated below by italics) is to adjust their boundaries as indicated in Fig. 2, namely: 


\begin{tabular}{|c|c|c|c|c|}
\hline $\mathrm{NZ}$ ages/stages & Criterion for definition & Age of base $(\mathrm{Ma})$ & Length (m.y.) & Isotope stage \\
\hline Base-Haweran & Base-Rangitawa Tephra & 0.34 & 0.34 & 10 \\
\hline Base-Putikian & Brunhes/Matuyama boundary & 0.78 & 0.44 & $19 / 20$ \\
\hline Base Okehuan & Base-Jaramillo Subchron & 1.07 & 0.29 & 31 \\
\hline Base-Castlecliffian & Base-Jaramillo Subchron & 1.07 & 0.73 & 31 \\
\hline Base Marahauan & Pliocene-Pleistocene boundary & 1.81 & 0.74 & $64 / 65$ \\
\hline$\overline{\text { Base Hautawan }}$ & Matuyama/Gauss boundary & 2.58 & $0 . \overline{77}$ & $\overline{104}$ \\
\hline Base-Nukumaruan & Matuyama/Gauss boundary & 2.58 & 1.51 & 104 \\
\hline Base-Mangapanian & Top-Kaena Subchron & 3.03 & 0.45 & G20 \\
\hline Base-Waipipian & Gauss/Gilbert boundary & 3.60 & 0.57 & $M G l$ \\
\hline Base-Waitotaran & Gauss/Gilbert boundary & 3.60 & 1.02 & MGI \\
\hline Base-Opoitian & Base-Thvera subchron & 5.25 & 1.65 & TG1 \\
\hline
\end{tabular}

That done, we can cease sterile argument about boundaries and get on with documenting more accurately the many correlation criteria that will allow New Zealand Pliocene-Pleistocene geological events to be viewed within the framework of the global 41000 year climatic cycle. At the same time, we will have preserved an important historical stratigraphic nomenclature for use in low-resolution or local studies.

\section{ACKNOWLEDGMENTS}

We thank James Cook University and the Australian Grants Committee for the financial support that made this research possible. We also thank Alan Beu and Peter Cawood for their perceptive criticisms of the draft manuscript, whilst exonerating them from responsibility for the views expressed. Coloured versions of Fig. 2 are available by email enquiry to geology@jcu.edu.au

\section{REFERENCES}

Abbott, S. T.; Carter, R. M. 1994: The sequence architecture of mid-Pleistocene (c. 1.1-0.4 Ma) cyclothems from New Zealand: facies development during a period of orbital control on sea level cyclicity. In: de Boer, P. L.; Smith, D. G. ed. Orbital forcing and cyclic sequences. International Association of Sedimentologists special publication 19: 367-394.

Aguirre, E.; Pasini, G. 1985: The Pliocene-Pleistocene boundary. Episodes 8: 116-120.

Alloway, B. V.; Pillans, B.; Sandhu, A. S.; Westgate, J. A. 1993 Revision of the marine chronology in Wanganui Basin, New Zealand, based on isothermal plateau fission-track dating of tephra horizons. Sedimentary geology 82: 299-310.

Bassett, M. G. 1985: Towards a "Common Language" in stratigraphy. Episodes 8: 87-92.

Berger, A.; Loutre, M. F. 1991: Insolation values for the climate of the last 10 m.y. Quaternary science reviews 10: 297-317.

Berggren, W. A.; van Couvering, J. A. 1979: Quaternary. In: Robinson, R. A.; Teichert, C. ed. Treatise on invertebrate paleontology. Part A, Introduction. Pp. A505-A543.

Berggren, W. A.; Kent, D. V.; Swisher, C. C.; Aubry, M. P. 1995: A revised Cenozoic geochronology and chronostratigraphy. In: Berggren et al. ed. Geochronology, time scales and global stratigraphic correlation. SEPM special publication 54 : 139-158.

Beu, A. G. 1969: Index macrofossils and New Zealand Pliocene and lower Pleistocene time-stratigraphy. New Zealand journal of geology and geophysics 12: 643-658.

Beu, A. G. 1990: Molluscan generic diversity of New Zealand Neogene stages: extinction and biostratigraphic events. Palaeogeography, paleoclimatology, palaeoecology 77: 279-288.
Beu, A. G. 1995: Pliocene limestones and their scallops: Litho stratigraphy, pectinid biostratigraphy and paleogeography of eastern North Island late Neogene limestones. Institute of Geological \& Nuclear Sciences monograph 10.

Beu, A. G.; Edwards, A. R. 1984: New Zealand Pleistocene and late Pliocene glacio-eustatic cycles. Palaeogeography, palaeoclimatology, palaeoecology 46: 119-142.

Beu, A. G.; Maxwell, P. A. (drawings by Brazier, R. C.) 1990: Cenozoic Mollusca of New Zealand. New Zealand Geological Surve: paleontological bulletin $58.518 \mathrm{p}$.

Beu, A. G.; Grant-Taylor, T. L.; Hornibrook, N. de B. 1977 : Nukumaruan records of the subantarctic scallop Chlamvi delicatula and crab Jacquinotia edwardsii in central Hawke' Bay. New Zealand journal of geology and geophysics 20 : 217-248.

Beu, A. G.; Edwards, A. R.; Pillans, B. J. 1987: A review of New Zealand Pleistocene stratigraphy, with emphasis on the marine rocks. In: Itihara, M.; Kamei, T. ed. Proceedings of the First International Colloquium on Quaternary Stratigraphy of Asia and the Pacific Area, Osaka. Osaka, Science Council of Japan Pp. 250-269.

Black, R. M. 1992: Chronology of the middle Pleistocene Kidnapper: Group, New Zealand, and correlation to global oxygen isotope stratigraphy. Earth and planetary science letters 109 573-584.

Boellstorff, J. D.; Te Punga, M. T. 1977: Fission-track ages anc correlation of middle and lower Pleistocene sequences from Nebraska and New Zealand. New Zealand journal of geolog? and geophysics 20: 47-58.

Boreham, A. U. E. 1963: Some problems concerning the applicatior. of the Lower Nukumaruan (Hautawan) Substage (lower Pleistocene, New Zealand). New Zealand journal of geology. and geophysics 6: 3-27.

Brasier, M.; Cowie, J.; Taylor, M. 1994: Decision on the PrecambrianCambrian boundary stratotype. Episodes 17: 3-8.

Bussell, R.; Mildenhall, D. C. 1990: Extinct palynomorphs from middle and late Pleistocene terrestrial sediments, South Wanganui Basin, New Zealand. New Zealand journal of geology and geophysics 33: 439-447.

Bussell, R.; Pillans, B. 1992: Vegetational and climatic history during oxygen isotope stage 9 , Wanganui district, New Zealand and correlation of the Fordell Ash. Journal of the Royal Society of New Zealand 22: 41-60.

Campbell, J. D. 1959: The Warepan Stage (Triassic); definition and correlation. New Zealand journal of geology and geophysics 2: 198-207.

Cande, S. C.; Kent, D. V. 1995: Revised calibration of the geomagnetic polarity timescale for the Late Cretaceous and Cenozoic. Journal of geophysical research 100: 6093-6095.

Carter, L.; Nelson, C. S.; Neil, H. L.; Froggatt, P. C. 1995: Correlation, dispersal, and preservation of the Kawakawa Tephra and other late Quaternary tephra layers in the Southwest Pacific Ocean. New Zealand journal of geology and geophysics 38: 29-46.

Carter, R. M. 1970: A proposal for the subdivision of Tertiary time in New Zealand. New Zealand journal of geology and geophysics 13: $350-363$. 
Carter, R. M. 1974: A New Zealand case-study of the need for local time-scales. Lethia 7: 181-202.

Carter, R. M.; Abbott, S. T.; Naish, T.; Saul, G. 1997: A shallow-marine glacio-eustatic cyclostratigraphy for the last $2.5 \mathrm{Ma}$, Wanganui Basin, New Zealand. Poster available from the Department of Earth Sciences, James Cook University.

Cita, M.; Castradori, D. 1997: Upper Pliocene - lower Pleistocene integrated marine stratigraphy: state of the art. In: Leroy, S.; Ravazzi, C. ed. Working Group on Milankovitch and PlioPleistocene vegetation succession from 2.6 to $0.9 \mathrm{Ma}$. InterINQUA Colloquium, Ankara, Abstracts. Pp. 13-15.

Cox, A.; Doell, R. R.; Dalrymple, G. B. 1964: Reversals of the Earth's magnetic field. Science 144: 1357-1543.

Edwards, A. R. 1987: An integrated biostratigraphy, magnetostratigraphy and oxygen isotope stratigraphy for the late Neogene of New Zealand. New Zealand Geological Survey record 23.

Edwards, A. R.; Hornibrook, N. de B.; Te Punga, M. T. 1981: In pursuit of the Pliocene-Pleistocene boundary. Geological Society of New Zealand newsletter 52: 21-28.

Emiliani, C. 1955: Pleistocene temperatures. Journal of geology 63: $538-578$.

Emiliani, C. 1966: Paleotemperature analysis of Caribbean cores P6403-8 and P6304-9 and a generalized temperature curve for the past 425,000 years. Journal of geology 74: 109-124.

Finlay, H. J. 1939: New Zealand Foraminifera: key species in stratigraphy, 1. Transactions of the Royal Society of New Zealand 68: 504-533.

Finlay, H. J.; Marwick, J. 1940: The divisions of the Upper Cretaceous and Tertiary of New Zealand. Transactions of the Royal Society of New Zealand 70: 77-135.

Finlay, H. J.; Marwick, J. 1947: New divisions of the New Zealand Upper Cretaceous and Tertiary. New Zealand journal of science and technology B28: 288-236.

Fleming, C. A. 1944: Molluscan evidence of Pliocene climatic change in New Zealand. Transactions of the Royal Society of New Zealand 74: 207-220.

Fleming, C. A. 1947: Standard sections and subdivisions of the Castlecliffian and Nukumaruan Stages in the New Zealand Pliocene. Transactions of the Royal Society of New Zealand 76: $300-326$.

Fleming, C. A. 1953a: The geology of the Wanganui Subdivision. New Zealand Geological Survey bulletin $52.362 \mathrm{p}$.

Fleming, C. A. 1953b: New evidence for world correlation of marine Pliocene. Australian journal of science 15: 135-136.

Fleming, C. A. 1955: Quaternary geochronology in New Zealand. Actes du IV Congres International du Quaternaire (Rome, September, 1953). Pp. 3-8.

Fleming, C. A. 1957: The genus Pecten in New Zealand. New Zealand Geological Survey paleontological bulletin 26.

Fleming, C. A. 1959: Lexique stratigraphique internationale, v. 6 Oceanie, fascicule 4, New Zealand. 527 p.

Fleming, C. A. 1962: New Zealand biogeography: a paleontologist's approach. Tuatara 10 (2): 53-108.

Fleming, C. A. 1975: The Quaternary record of New Zealand and Australia. The Royal Society of New Zealand bulletin 13: 1-20.

Gammon, P. 1997: The sequence stratigraphy of the Mangaopari Basin. Unpublished PhD dissertation, James Cook University of North Queensland, Townsville.

Gammon, P. R.; Barton, C. E. in press: Magnetostratigraphy of the Mangaopari Basin. Earth and planetary science letters.

Harland, W. B.; Armstrong, R. L.; Cox, A. L.; Craig, L. E.; Smith, A. G.; Smith; D. G. 1990: A geologic time scale 1989. Cambridge, Cambridge University Press. 263 p.

Hays, J. D.; Shackleton, N. J. 1976: Globally synchronous extinction of the radiolarian Stylatractus universus. Geology 4: 649-652.

Hays, J. D.; Imbrie, J.; Shackleton, N. J. 1976: Variations in the Earth's orbit: pacemaker of the ice ages. Science 194: 1121-1132.
Hilgen, F. J. 1987: Sedimentary rhythms and high-resolution chronostratigraphic correlations in the Mediterranean Pliocene. Newsletters in stratigraphy 17: 109-127.

Hilgen, F. J. 1991 a: Astronomical calibration of Gauss to Matuyama sapropels in the Mediterranean and implications for the geomagnetic polarity timescale. Earth and planetary science letters 104: 226-234.

Hilgen, F. J. 1991b: Extension of the astronomically calibrated (polarity) timescale to the Miocene/Pliocene boundary. Earth and planetary science letters 107: 349-368.

Hornibrook, N. deB. 1981: Globorotalia (planktic Foraminiferida) in the late Pliocene and early Pleistocene of New Zealand. New Zealand journal of geology and geophysics 24: 263-293.

Hornibrook, N. deB. 1982a: Late Miocene to Pleistocene Globorotalia (Foraminiferida) from DSDP Leg 29, Site 284, Southwest Pacific. New Zealand journal of geology and geophysics 25 : 83-99.

Hornibrook, N. deB. 1982b: In: Hoskins, R. H. ed. Stages of the New Zealand marine Cenozoic: a synopsis. New Zealand Geological Survey report 107. $74 \mathrm{p}$.

Hornibrook, N. deB.; Brazier, R. C.; Strong, C. P. 1989: Manual of New Zealand Permian to Pleistocene foraminiferal biostratigraphy. New Zealand Geological Survey paleontological bulletin 56.

House, M. R. 1988: International definition of Devonian System boundaries. Proceedings of the Usher Society 7: 41-46.

Hughes, N. F.; Williams, D. B.; Cutbill, J. L.; Harland, W. B. 1967: A use of reference-points in stratigraphy. Geological magazine 104: $634-635$.

Jenkins, D. J. 1971: Stratigraphic position of the New Zealand Pliocene-Pleistocene boundary. Comment. New Zealand journal of geology and geophysics 14: 418-422.

Journeaux, T. D.; Kamp, P. J. J.; Naish, T. R. 1996: A lithostratigraphic framework for Middle Pliocene cyclothems, Mangaweka region, Wanganui Basin, New Zealand. New Zealand journal of geology and geophysics 39: 135-149.

Kamp, P. J. J. 1978: Stratigraphy and sedimentology of conglomerates in the Pleistocene Kidnappers Group, Hawke's Bay. Unpublished MSc thesis, lodged in the Library, University of Waikato, Hamilton, New Zealand.

Kamp, P. J. J. 1990: Field notes, middle Pleistocene Kidnappers Group, Hawke's Bay. Geological Society of New Zealand miscellaneous publication 50B: 105-118.

Kennett, J. P.; Watkins, N. D. 1974: Late Miocene - Early Pliocene paleomagnetic stratigraphy, paleoclimatology and biostratigraphy in New Zealand. Geological Society of America bulletin 85: 1385-1398.

Kennett, J. P.; Watkins, N. D.; Vella, P. 1971: Paleomagnetic chronology of Pliocene-early Pleistocene climates and the Pliocene-Pleistocene boundary in New Zealand. Science 17I: 276-279.

King, W. B. R.; Oakley, K. P. 1950: Report of the Temporary Commission on the Pliocene-Pleistocene boundary, appointed 26th August, 1948. 18th International Geological Congress (Great Britain, 1948), part 1, general proceedings. Pp. 213-214.

Kohn, B. P.; Pillans, B.; McGlone, M. S. 1992: Zircon fission-track age for middle Pleistocene Rangitawa Tephra, New Zealand: stratigraphic and paleoclimatic significance. Palaeogeography, palaeoclimatology, palaeoecology 95: 73-94.

Laskar, J. 1990: The chaotic motion of the solar system: a numerical estimate of the size of the chaotic zones. Icarus 88: 266-291.

Lourens, L. J.; Antonarakou, A.; Hilgen, F. J.; Van Hoof, A. A. M.; Vergnaud-Grazzini, C.; Zachariasse, W. J. 1996a: Evaluation of the Plio-Pleistocene astronomical timescale. Paleoceanography II: 391-413.

Lourens, L. J.; Hilgen, F. J.; Raffi, I.; Verngaud-Grazzini, C. 1996b: Early Pleistocene chronology of the Vrica section (Calabria, Italy). Paleoceanography 11: 797-812. 
Martinsson, A. ed. 1977: The Silurian-Devonian boundary. International Union of Geological Sciences series A(5).

Marwick, J. 1924a: Paleontological notes on some Pliocene Mollusca from Hawke's Bay. Transactions of the New Zealand Institute 55: 191-202.

Marwick, J. 1924b: The Struthiolariidae. Transactions of the New Zealand Insitute 55: 161-190.

Miall, A. D. 1996: The geology of stratigraphic sequences. SpringerVerlag. $433 \mathrm{p}$.

Milne, J. D. G. 1973a: Upper Quaternary geology of the Rangitikei drainage basin, North Island, New Zealand. Unpublished PhD thesis, lodged in the Library, Victoria University of Wellington, Wellington, New Zealand.

Milne, J. D. G. 1973b: Mt Curl tephra, a 230,000 year old marker bed in New Zealand and its implications for Quaternary chronology. New Zealand journal of geology and geophysics I6: 519-532.

Milne, J. D. G. 1973c: Map and sections of river terraces in the Rangitikei Basin, North Island, New Zealand. Four sheets. New Zealand soil survey report 4.

Morgans, H. E. G.; Scott, G. H.; Beu, A. G.; Graham, I. J.; Mumme, T. C.; St George, W.; Strong, C. P. 1996: New Zealand Cenozoic time scale. New Zealand Institute of Geological \& Nuclear Sciences science report 96/38.

Morley, J. J.; Shackleton, N. J. 1978: Extinction of the radiolarian Stylatractus universus as a biostratigraphic datum to the Atlantic Ocean. Geology 6: 309-311.

Naish, T. R.; Kamp, P. J. J. 1995: Late Pliocene marine cyclothems, Wanganui Basin, New Zealand: a lithostratigraphic framework. New Zealand journal of geology and geophysics 38: 223-243.

Naish, T. R.; Kamp, P. J. J. 1997: High-resolution sequence stratigraphy of 6 th order (41 ka) Plio-Pleistocene cyclothems, Wanganui Basin, New Zealand: a case for the regressive systems tract. Geological Society of America bulletin 109: 978-999.

Naish, T. R.; Kamp, P. J. J.; Alloway, B. V.; Pillans, B. J.; Wilson, G. S.; Westgate, J. A 1996: Integrated tephrochronology and magnetostratigraphy for cyclothemic marine strata, Wanganui Basin: implications for the Pliocene-Pleistocene boundary in New Zealand. Quaternary international 34/36: 29-48.

Naish, T.; Kamp, P. J. J.; Pillans, B. 1997: Recurring global sea-level changes recorded in shelf deposits near the $\mathrm{G} / \mathrm{M}$ polarity transition, Wanganui Basin, New Zealand: implications for redefining the Plio-Pleistocene boundary. Quaternary international 40: 61-71.

Naish, T.; Beu, A. G.; Carter, R. M.; Edwards, A. R.; Kamp, P. J. J.; Pillans, B.; Saul, G.; Woolfe, K. in press: Astronomical calibration of a southern hemisphere Plio-Pleistocene reference section, Wanganui Basin, New Zealand. Quaternary science reviews.

Neef, G. 1970: Notes on the subgenus Pelicaria. New Zealand journal of geology and geophysics 13: 436-476.

Nelson, C. S.; Froggatt, P. C.; Gosson, G. J. 1985a: Nature, chemistry, and origin of late Cenozoic megascopic tephras in Leg 90 cores from the southwestern Pacific. In: Kennett, J. P.; von der Borch, C. C. et al. ed. Initial reports of the Deep Sea Drilling Project 90: 1161-1171.

Nelson, C. S.; Hendy, C. H.; Cuthbertson, A. M.; Jarrett, G. R. 1985b: Late Quaternary carbonate and isotope stratigraphy, subantarctic Site 594, southwest Pacific. In: Kennett, J. P.; von der Borch, C. C. et al. ed. Initial reports of the Deep Sea Drilling Project 90: 1425-1436.

Ninkovitch, D. 1968: Pleistocene volcanic eruptions in New Zealand recorded in deep sea sediments. Earth and planetary science letters 4: 89-102.

Opdyke, N. D. 1968: The paleomagnetism of ocean cores. In: Phinney, R. A. ed. History of the Earth's crust. Princeton University Press. Pp. 67-72.

Payton, C. E. ed. 1977: Seismic stratigraphy-applications to hydrocarbon exploration. American Association of Petroleum Geologists memoir $26.516 \mathrm{p}$.
Pillans, B. J. 1983: Upper Quaternary marine terrace chronology ani: deformation, South Taranaki, New Zealand. Geology II 292-297.

Pillans, B. 1988: Loess chronology in Wanganui Basin, New Zealand In: Eden, D. N.; Furkert, R. J. ed. Loess: its distribution. geology, and soils. Rotterdam, Balkema. Pp. 175-191.

Pillans, B. 1990: Late Quaternary marine terraces, south TaranakiWanganui (Sheet Q22 and part sheets Q20, Q21, R21 \& R22, 1:100 000. New Zealand Geological Survey miscellaneou series map 18.

Pillans, B. J. 1991: New Zealand Quaternary stratigraphy: an overvieu Quaternary science reviews 10: 405-418.

Pillans, B. 1994: Direct marine-terrestrial correlations, Wangand Basin, New Zealand: the last 1 million years. Quaternar. science reviews 13: 189-200.

Pillans, B. J.; McGlone, M.; Palmer, A.; Mildenhall, D.; Alloway, B Berger, G. 1993: The last glacial maximum in central an. southern North Island, New Zealand: a paleoenvironmenta reconstruction using Kawakawa Tephra Formation as the chronostratigraphic marker. Paleogeography, paleo. climatology, paleoecology 101: 283-304.

Pillans, B. J.; Roberts, A. P.; Wilson, G. S.; Abbott, S. T.; Allowav B. V. 1994: Magnetostratigraphic, lithostratigraphic, and tephrostratigraphic constraints on lower and middle Pleistocene sea-level changes, Wanganui Basin, New Zealand Earth and planetary science letters 121:81-98.

Quinn, T. R.; Tremaine, S.; Duncan, M. 1991: A three million year integration of the Earth's orbit. Journal of astronomy $10 \mathrm{~A}$ : 2287-2305.

Raymo, M. E.; Ruddiman, W. F.; Backman, J.; Clement, B. M. Martinson, D. G. 1989: Late Pliocene variation in northern hemisphere ice sheets and North Atlantic deep-water circulation. Paleoceanography 4: 413-446.

Remane, J.; Bassett, M. G.; Cowie, J. W.; Gohrbandt, K. H.; Lane. H. R.; Michelsen, O.; Naiwen, W. 1996: Revised guidelines for the establishment of global chronostratigraphic standarcs by the International Commission on Stratigraphy (ICS) Episodes 19: 77-81.

Ruddiman, W. F.; Raymo, M. E.; Martinson, D. G.; Clement, B. M Backman, J. 1989: Pliocene evolution: Northern Hemispher: ice sheets and the North Atlantic Ocean. Paleoceanograph: 4: 353-412.

Saul, G.; Naish, T.; Abbott, S. T.; Carter, R. M. in press: Sedimentary cyclicity in the marine Plio-Pleistocene: sequence stratigraph motifs characteristic of the last 2.5 Ma. Geological Society of America bulletin.

Scott, G. 1982: Review of Kapitean stratotype and boundary with Opoitian Stage (upper Neogene, New Zealand). New Zealand journal of geology and geophysics 25: 475-485.

Scott, G. H.; Bishop, S.; Burt, B. J. 1990: Guide to some Neoger globorotalids (Foraminiferida) from New Zealand. Ne. Zealand Geological Survey paleontological bulletin $61.135 \mathrm{p}$

Seward, D. 1974: Age of New Zealand Pleistocene substages b. fission-track dating of glass shards from tephra horizons. Eary and planetary science letters 24: 242-248.

Seward, D. 1976: Tephrostratigraphy of marine sediments in Wanganui Basin, New Zealand. New Zealand journal of geology ari, geophysics 19: 9-20.

Seward, D. 1979: Comparison of zircon and glass fission-track ages from tephra horizons. Geology 7: 79-82.

Seward, D.; Christoffel, D. A.; Lienert, B. 1986: Magnetic polarit: stratigraphy of a Pliocene-Pleistocene marine sequence of North Island, New Zealand. Earth and planetary science letters 80: 353-360.

Shackleton, N. J.; Opdyke, N. D. 1973: Oxygen isotope ard palaeomagnetic stratigraphy of equatorial Pacific core V $2 ;.$ 238: oxygen isotope temperatures and ice volumes on a 11 and $10^{6}$ year scale. Quaternary research 3: 39-59.

Shackleton, N. J.; Opdyke, N. D. 1976: Oxygen isotope and paleomagnetic stratigraphy of Pacific core V28-239 Late Pliocene to latest Pleistocene. Geological Society of America memoir 145: 449-464. 
Shackleton, N. J.; Berger, A.; Peltier, W. R. 1990: An alternative astronomical calibration of the lower Pleistocene timescale based on ODP Site 677. Transactions of the Royal Society of Edinburgh 81: 251-261.

Shackleton, N. J.; Hall, M. A.; Pate, D. 1995a: Pliocene stable isotope stratigraphy of ODP site 846 . In: Pisias, N.; Mayer, L. Janacek, T. et al. ed. Proceedings of Ocean Drilling Program scientific results 138: 337-353.

Shackleton, N. J.; Crowhurst, S.; Hagelberg, T.; Pisias, N.; Schneider, D. A. 1995b: A new late Neogene timescale: application to leg 138 sites. Proceedings of Ocean Drilling Program scientific results 138: 73-101.

Shane, P. A. R. 1990: Correlation of some Pliocene tuffs in southern Wairarapa, New Zealand, and the comparison with biostratigraphic and magnetostratigraphic data. New Zealand journal of geology and geophysics 33: 349-355.

Shane, P. A. R. 1994: A widespread early Pleistocene tephra (Potaka tephra, $1 \mathrm{Ma}$ ) in New Zealand: character, distribution, and implications. New Zealand journal of geology and geophysics 37: $25-36$.

Shane, P. A. R.; Froggatt, P. C. 1991: Glass chemistry, paleomagnetism, and correlation of middle Pleistocene tuffs in southern North Island, New Zealand, and western Pacific. New Zealand journal of geology and geophysics 34: 203-211.

Shane, P. A. R.; Black, T. M.; Alloway, B. V.; Westgate, J. A. 1996 : Early to middle Pleistocene tephrochronology of North Island New Zealand: implications for volcanism, tectonism, and paleoenvironments. Geological Society of America bulletin 108: 915-925.

Shepherd, M. J.; Price, D. M. 1990: Thermoluminescence dating of late Quaternary dune sand, Manawatu/Horowhenua area, New Zealand: a comparison with ${ }^{14} \mathrm{C}$ age determinations. New Zealand journal of geology and geophysics 33: 535-539.

Suggate, R. P. 1990: Late Pliocene and Quaternary glaciations of New Zealand. Quaternary science reviews 9: 175-195.

Te Punga, M. T. 1981: The Pliocene/Pleistocene boundary and the Nukumaruan stage. New Zealand Geological Survey report 96: $1-19$.

Thierstein, H. R.; Geitzenauer, K. R.; Molfino, B.; Shackleton, N. J. 1977: Global synchroneity of late Quaternary coccolith datum levels: validation by oxygen isotopes. Geology 5: 400-404.

Thomson, J.A. 1916: On the names applicable to the division for the Tertiary in New Zealand. Transactions of the New Zealand Institute 48: 28-40.

Tiedemann, R.; Samthein, M.; Shackleton, N. J. 1994: Astronomical timescale for the Pliocene Atlantic $\delta^{18} \mathrm{O}$ and dust flux records of Ocean Drilling Program site 659. Paleoceanography 9: 619-638.
Turner, G. M.; Kamp, P. J. J. 1990: Paleomagnetic location of the Jaramillo Subchron and the Matuyama-Brunhes transition in the Castlecliff stratotype section, Wanganui Basin, New Zealand. Earth and planetary science letters 100: 42-50.

Vail, P. R.; Audemard, F.; Bowman, S. A.; Eisner, P. N.; Perez-Cruz, C. 1991: The stratigraphic signatures of tectonics, eustasy and sedimentology-an overview. In: Einsele, G.; Ricken, W.; Seilacher, A. ed. Cycles and events in stratigraphy. SpringerVerlag. Pp. 617-659.

van Donk, J. 1976: $\mathrm{O}^{18}$ record of the Atlantic Ocean for the entire Pleistocene Epoch. Geological Society of America memoir 145: $147-163$.

Vella, P. 1963: Pliocene-Pleistocene cyclothems, Wairarapa, New Zealand. Transactions of the Royal Society of New Zealand geology 2: 15-50.

Vella, P. 1975: The boundaries of the Pliocene in New Zealand. In: Saito, T.; Burkle, L. H. ed. Late Neogene Epoch boundaries. Special publication 1. New York, Micropalaeontology Press. Pp. 85-93.

Watkins, N. D.; Huang, T. C. 1977: Tephras in abyssal sediments east of New Zealand: chronology, paleowind velocity, and paleoexplosivity. New Zealand journal of geology and geophysics 20: 179-198.

Wilde, R. H.; Vucetich, C. G. 1988: Aeolian cover beds of marine terraces in the western Wanganui district, North Island, New Zealand. In: Eden, D. N.; Furkert, R. J. ed. Loess, its distribution, geology and soils. Rotterdam, Balkema. Pp. 215-232.

Williams, D. F.; Thunell, R. C.; Tappa, E.; Domenico, R.; Raffi, I. 1988: Chronology of the Pleistocene oxygen isotope record: 0-1.88 m.y. B.P. Palaeogeography, palaeoclimatology, palaeoecology 64: 221-240.

Wilson, G. S. 1993: Ice induced sea-level changes in the late Neogene. Unpublished PhD thesis, lodged in the Library, Victoria University of Wellington, Wellington, New Zealand.

Wilson, C. J. N.; Houghton, B. F.; Kamp, P. J. J.; McWilliams, M. A. 1995: An exceptionally widespread ignimbrite with implications for pyroclastic flow emplacement. Nature 378 : 605-607.

Wilson, C. J. N.; Switsur, V. R.; Ward, A. P. 1988: A new ${ }^{14} \mathrm{C}$ age for the Oruanui (Wairakei) eruption, New Zealand. Geological magazine 125: 297-300.

Zijderveld, J. D. A.; Hilgen, F. J.; Langereis, C. G.; Verhallen, P. J. J. M.; Zachariasse, W. J. 1991: Integrated magnetostratigraphy and biostratigraphy of the Upper Pliocene lower Pleistocene from Monte Singa and Crotone areas in Calabria, Italy. Earth and planetary science letters 107: 697-714. 